\title{
Tendencies and Characteristics of Feedback Given by Primary English Language Teachers in Croatia ABSTRACT
}

Feedback is a constituent part of three assessment approaches: assessment forlas/of learning. Feedback about students' learning and performance differs in the three approaches with respect to manner and purpose. Feedback associated with assessment of learning is representative of the traditional way of teaching, its role reduced to mere reporting of a score or grade. However, in the context of assessment for learning and assessment as learning, feedback plays a more significant role. It implies having a clear understanding of how, when and why feedback is given in addition to involving students in giving feedback. This preliminary research on a sample of primary school English language teachers in Croatia focuses on tendencies in giving feedback and some general characteristics of feedback given to students within the assessment for learning approach. Teachers' estimates of their competence in providing feedback and their needs in this particular area of assessment are revealed. The results will pinpoint areas which require further research for the purpose of more closely adhering to the principles of assessment for learning and assessment as learning in English language teaching.

Keywords: assessment approaches; assessment for learning; feedback; formative assessment

\section{Smernice in značilnosti dajanja povratnih informacij pri pouku angleščine $v$ osnovni šoli}

\author{
POVZETEK
}

Povratne informacije so sestavni del treh ocenjevalnih pristopov: ocenjevanje za učenjelkot učenjel učenja. Podajanje povratnih informacij o učenju in uspešnosti se v teh pristopih razlikuje glede načina in namena. Povratne informacije v okviru ocenjevanja učenja so značilne za tradicionalni način učenja; njihova vloga je zmanjšana zgolj na točkovanje in ocene. Nasprotno pa je vloga povratnih informacij v ocenjevanju za učenje in ocenjevanju kot učenju mnogo bolj pomembna. Povezana je z jasnim razumevanjem, kako, kdaj in zakaj so povratne informacije podane, hkrati pa so v podajanje povratnih informacij vključeni tudi študenti. $V$ predhodni raziskavi, $v$ kateri je sodelovalo nekaj osnovnošolskih učiteljev angleščine na Hrvaškem, smo ugotavljali smernice in splošne značilnosti pri podajanju povratnih informacij v okviru pristopa ocenjevanja za učenje. Učitelji so ocenjevali svoje kompetence pri podajanju povratnih informacij in predstavili svoje potrebe pri tej vrsti ocenjevanja. Rezultati so pokazali področja, kjer je potrebno nadaljnje raziskovanje za zagotovitev boljšega upoštevanja načel ocenjevanja za učenje in ocenjevanja kot učenja pri pouku angleškega jezika.

Ključne besede: ocenjevalni pristopi; ocenjevanje za učenje; povratne informacije; formativno ocenjevanje 


\section{Tendencies and Characteristics of Feedback Given by Primary English Language Teachers in Croatia}

\section{Introduction}

In 2016, in Croatia, a team of experts created and proposed the document Framework for the Assessment of Learning Processes and Outcomes [Draft] (2016) (later in text Framework for Assessment). The document, among other issues related to assessment, presented the three approaches to assessment and particularly the importance and purpose of feedback in the two approaches, assessment for and assessment as learning. Furthermore, the Framework for Assessment refers to feedback as gathered information used to guide learning and improve learning and teaching. Therefore, the two assessment approaches, assessment for and assessment as learning, have a very important formative purpose. The purpose of the third approach, assessment of learning is summative - it evaluates the acquisition of educational outcomes after a particular period. Within the latter approach, feedback serves as guidance for further learning/teaching, as opposed to the purpose of feedback in the former assessment approaches, where it is directed towards the process of learning and teaching at present.

In light of the proposed Framework for Assessment, the aim of this research is to establish the level and characteristics of feedback prevailing among English language teachers in a primary school in Croatia, particularly with regard to the assessment for learning approach. It is expected that the findings will also reveal teachers' competences in providing such feedback and establish needs in that particular area of assessment. In that respect, the findings may contribute to improving formative classroom assessment practices and to providing information relevant for teacher trainers and institutions responsible for providing teachers with opportunities for effective professional development.

\section{The Formative Role of Feedback within the Assess- ment for Learning Approach}

The term 'formative assessment' became popular in the 1990s, when there was concern that students were over-assessed and too much testing was being carried out (Bennett 2011). This way of assessing, judging learning by generating and reporting scores and grades, was referred to as 'assessment for testing', or the term used today, 'assessment of learning.' In a booklet entitled Inside the Black Box (1998), Paul Black and Dylan William conclude, among other things, that the function of grading is overemphasised, while the function of learning is neglected. They thus suggest including feedback into teaching practice, which will serve to guide students and lead them to progress in learning. Sadler $(1998,120)$ accepts the definition of feedback as information about how successfully something has been or is being done, but warns that few physical, intellectual or social skills can be satisfactorily acquired simply by being told about them. He emphasizes the effect rather than informational content of feedback: "Feedback is information about the gap between the actual level and the reference level of a system parameter which is used to alter the gap in some way" (Ramaprasad 1983, 4, cited in Sadler 1998, 120). Emphasis on feedback as a method for improving learning and experiencing achievement led to different interventions in teaching. For instance, in the American educational system, the quality of feedback which teachers offer their students took on a more dominant role with the initial implementation of the No Child Left Behind Act (U.S. Department of Education 2001). Over 
the years, however, the Act was reviewed and evolved to the present-day Every Student Succeeds Act (U.S. Department of Education 2015), which is characterised by being open to other forms of assessment instead of a snapshot test score, and examining student growth in order to determine how well students are doing and the progress they have made. Formative assessment thus became a more efficient tool for improving not only student achievement, but also teaching practice (Dunn and Mulvenon 2009, 3). This is because the goal of formative assessment is also to provide teachers with immediate feedback, so they can adjust their instruction (MacDonald et al. 2015, xviii). Teachers can thus determine what to do next instructionally, i.e., what strategies and methods to apply to improve their teaching in order for students to improve their learning.

In Croatia, feedback in teaching is mentioned in the document Croatian National Educational Standard (Ministry of Science, Education and Sports 2005) and the Teaching Curriculum for Primary School (Ministry of Science, Education and Sports 2006). These documents refer to feedback in the context of constructive information on the summative assessment of students and their progress, development and behaviour in a way that "students and parents/guardians understand the need for educational intervention and ways of further development and progress." Although there is mention of teaching that is interactive, problem oriented and constructivist, the joint work of students and teachers and joint assessment of achievement, the use of constructive feedback and its application in formative assessment is not explained. Only in the document Framework for Assessment (Draft) (Ministry of Science, Education and Sports 2016) are the concepts of feedback and formative assessment defined. This document states that feedback to students based on the two approaches to assessment, for learning and as learning, does not result in a grade, but in an exchange of information on learning and the results of learning. Feedback is a means of recognizing where students are at in their learning with respect to the set outcomes, and the effectiveness of the application of certain learning strategies.

In short, feedback within assessment for learning is a constituent part of the teaching process that is usually given by the teacher while teaching in the form of information on the ways in which a student has acquired and interpreted the focal learning material. Feedback in this approach is the channel which teachers and students adopt in the attempt to answer three questions, Where am I going? (What are the goals?), How am I doing? (What progress is being made towards the goal?), and What next? (What activities need to be undertaken to make better progress?) (Hattie and Timperley $(2007,86)$. From a temporal perspective, these can be expressed as the present, linked with assessment of student learning up to now, and activities that will be undertaken for the purpose of improvement from now on.

\section{About Levels, Timing and Effect of Feedback}

Hattie and Timperley $(2007,90)$, define four levels of feedback as follows: feedback about the task - FT (whether the task was completed, whether the answer was correct or incorrect); feedback about processing of the task - FP (involves construction of meaning, relates to strategies for error detection); feedback about self-regulation - FR (which affects self-efficacy, provides insight into one's knowledge, implies autonomy, self-direction, self-control and self-discipline, all directed to better understanding or completion of a task); and feedback about the self as a person - FS (the level of feedback directed towards the student as a person). The authors claim that the last level, feedback about the self as a person, characterised by feedback in the form of "You're an excellent student" or "That is an intelligent answer, great!" is the least efficient in terms of referring to the task itself. Still, it should be kept in mind that feedback in the form of praise can have a positive effect on 
learning, but only under the condition that it leads to changes in student effort, involvement in learning or the feeling of efficiency with respect to learning or the strategies used for understanding a task (ibid.). According to Gass and Selinker (2001), motivation is a social psychological factor and predictor of success in second language learning. Since there are various types of feedback that motivate language learning, feedback can be a means for motivating students' learning of a foreign language (Petchprasert 2012, 1113). Therefore, it is necessary to differentiate between feedback as praise, which is directed to the student and diverts from the task (as it gives insufficient information on the value of learning and achievement), from feedback directed towards effort, self-regulation, involvement or processes related with the task and achievement (FR), e.g., "You used appropriate phrases, and the sentences are grammatically correct." (ibid).

The timing of feedback, more precisely, the efficiency of giving immediate or delayed feedback, has also been subject of numerous studies. Giving immediate or delayed feedback can be efficient depending on the level of feedback in question. For instance, Clariana, Wagner and Roher Murphy (2000) established that immediate feedback is more efficient when it provides feedback about the task (FT), while delayed feedback is more efficient when it refers to the process of task completion (FP). In her book on effective feedback, Brookhart (2008) offers teachers some general advice on timing feedback, such as "put yourself in the student's shoes," i.e., they should ask themselves When would students like to hear some feedback?. The answer suggested by the author is While they are still thinking about the task and I can step in. The timing of feedback also needs to adhere to the principles of practicality in the teaching and learning process. Fluckiger et al. $(2010,140)$ offer strategies (shared revisions of student-generated questions and statements, using collaborative technology, mid-term conferencing, and so on) which give feedback sufficient time for revisions to occur, providing scaffolding for learners, inform instruction, and most importantly, involve students as partners in assessment.

With respect to the effects of feedback on learning, along with motivational feedback, there is feedback of a corrective nature, referred to as negative feedback. There are two types of corrective feedback: explicit or direct, and implicit or indirect feedback. Varnosfadrani and Basturkmen (2009; cited in Petchprasert 2012, 1115) define explicit feedback as "the process of giving direct forms of feedback." In a writing task, for example, explicit or direct feedback would comprise marking and correcting errors, or as Bitchener and Ferris (2013) propose correcting grammar/ errors, (the wrong word is crossed out and the right word is given). In a written script, forms of indirect feedback can be symbols or codes for correcting. In spoken tasks, direct feedback would imply interrupting and correcting students, while implicit feedback would be defined as identifying the type of error without correcting it (Bitchener et al. 2005; cited in Petchprasert 2012). Various strategies can be applied in a spoken context, such as asking for clarification by repeating the student's sentence with a rising intonation (She goed shoppingyesterday?) or indicating the type of mistake (irregular verb) and giving the student sufficient time for correction. In their seminal work, Lyster and Ranta $(1997,44)$ developed a model of error treatment sequence and identified six different types of feedback in communicatively oriented classrooms: explicit correction, recasts, clarification requests, metalinguistic feedback, elicitation and repetition. They also identified 'uptake', i.e., students' utterances immediately following teacher's feedback as uptake that results in repair of the error or uptake that results in an utterance that still needs repair. Their findings show that the feedback-uptake sequence engages students more actively when there is negotiation of form (not provided by recasts and explicit correction) and that students' turn in error treatment (through peer or self-repair or in need of repair) does not break the communicative flow. However, the authors caution that for such a negotiated form 
to take place, learners should possess an adequate proficiency in the L2. There are many second language acquisition theories relating to corrective feedback and its implications for learning, and they are far from being unanimous in their conclusions. According to El Tatawy's (2002) review of the related literature, they extend from nativist theories advocated by Chomsky (1975) and Krashen (1982), where negative evidence has a minute effect on language acquisition, to advocates of the noticing hypothesis, who argue that a degree of noticing must occur in SLA for input to become intake in L2 learning (Schmidt 1990, 1995; Schmidt and Frota 1986). This view is challenged by Gass $(1988,1990)$, who claims that without direct or frequent corrective feedback in the input, which would permit learners to detect discrepancies between their learner language and the target language, fossilization might occur, in other words, mere presentation of comprehensible input does not lead to intake and output Long's 'interaction hypothesis' (e.g., 1983) states that providing learners with both positive and negative evidence facilitates language acquisition, i.e., interaction that includes implicit corrective feedback is facilitative of L2 development. Furthermore, in content-based and communicative language classes, students show major improvements in accuracy if communication tasks are accompanied by negative feedback and other types of focus on form (e.g., Lightbown and Spada 1990; Doughty and Varela 1998; Doughty and Williams 1998). ${ }^{1}$ Kuo $(2003,10)$ claims that a primary task for language teachers is to "discern the optimal tension between positive and negative feedback," striking a balance that offers enough encouragement to motivate the learner, but not so much that errors are overlooked.

Giving feedback is an important link in determining the students' quality of work and in assessing their performance and achievement. With this research, we wanted to gain insights into the characteristics of feedback that primary school English language teachers tend to give their students. Furthermore, the opinions of teachers as to how their students experience feedback, and as to whether they are competent in providing feedback, will shed light on the needs that teachers may have in this area of assessment.

\section{Methodology}

\subsection{Research Aims}

Considering that the documents Croatian National Educational Standard (2005), Teaching Curriculum for Primary School (2006) and Framework for Assessment (Draft) (2016) encourage the use of formative assessment, the aim of this research was to gain insights into the level and nature of feedback prevailing among English language teachers in primary school in Croatia. More precisely, we sought answers to the following research questions:

1. When and how frequently do English language teachers in primary school provide feedback?

2. What is the nature of the feedback they provide, and which strategies do teachers use in giving feedback?

3. How, according to teachers' opinions, does feedback affect their students?

4. Do teachers find themselves competent in providing feedback to students?

For a more comprehensive review of the literature related to the theories and research behind corrective feedback, see El Tatawy, 2002, "Corrective feedback in second language acquisition". Working Papers in Applied Linguistics \& TESOL 2 (2). Columbia University. 
The research conducted was of a preliminary nature aimed at assessing the current situation regarding tendencies in giving feedback by primary English language teachers. The results should reveal teacher awareness of their use of feedback in teaching, areas that are possibly mismatched in terms of task and feedback, i.e., providing feedback that adheres to the principles of assessment for learning. The results should encourage further research that will more precisely detect issues related to assessment and feedback in teaching practice.

\subsection{Sample of Participants}

The sample of participants included English language teachers in the city of Zagreb and surrounding counties who teach English in primary school (grades 1-8). A total of 161 English language teachers responded to the survey. The teachers were not selected according to specific criteria, and therefore the sample is random.

\subsection{Instrument and Data Collection}

The research was conducted using the survey method, where the instrument was an anonymous questionnaire for English language teachers in primary school. The questionnaire contained 20 items in the form of closed-ended questions and Likert-type scale questions ( 1 - strongly agree, 2 - agree, 3 - neither agree nor disagree, 4 - disagree, 5 - strongly disagree). The questions were grouped into five categories: A - frequency and time of feedback, B - feedback content, C strategies used in giving feedback, D - effect of feedback on students, E - assessment of teacher's competence in providing feedback and need for further training. The survey was conducted from September to October 2016 in an online environment, where the participants selected their answer by clicking one of the provided options. Data were analysed using the SPSS statistical program and the descriptive analysis method.

\section{Results and Discussion}

\subsection{Frequency and Time of Giving Feedback}

The first statement in the questionnaire asked teachers to estimate in general the frequency of providing feedback to students by selecting one of four options (always, sometimes, rarely, never). According to their answers, $83.9 \%$ of the participants always provide feedback to students about their performance, while the remaining $16.1 \%$ give feedback occasionally. Considering the timing of feedback about student performance, i.e., whether it is immediate or delayed, Table 1 shows that $61.5 \%$ (99) of teachers give immediate feedback, i.e., right after the student's performance, while $38.5 \%$ (62) provide such feedback sometimes. Half of the participants in the sample, $50.9 \%$ (82), sometimes give delayed feedback, while 29.2\% (47) offer such feedback rarely, and $13 \%$ (22) never do so. A rather small percentage of the participants $5.6 \%$ always give delayed feedback.

Immediate feedback, also known as "on-the-spot" correction is efficient and even desired when solving "easy tasks" which do not require cognitive processing about the task itself. It is often used in oral tasks where recall of information and accuracy is called for. According to Brookhart (2008), immediate feedback is useful when factual knowledge is desired. If students are engaged in thinking about a task and working on it, feedback should be given without much delay so as to answer their How am I doing? questions and direct them to Where am I going? Delayed 
feedback, on the other hand, is useful with tasks that are focused on thinking and processing. If feedback refers to a written task, the student should be given such feedback in the next lesson.

TABLE 1. Frequency of providing immediate and delayed feedback to student performance.

\begin{tabular}{|l|c|c|c|c|}
\hline & \multicolumn{2}{|c|}{ Immediate feedback } & \multicolumn{2}{c|}{ Delayed feedback } \\
\hline & $\mathbf{f}$ & $\mathbf{\%}$ & $\mathbf{f}$ & $\%$ \\
\hline Never & & & 22 & 13.7 \\
\hline Rarely & & & 47 & 29.2 \\
\hline Sometimes & 62 & 38.5 & 82 & 50.9 \\
\hline Always & 99 & 61.5 & 9 & 5.6 \\
\hline *No answer & & & 1 & \\
\hline Total & 161 & 100 & 161 & 100 \\
\hline
\end{tabular}

The choice of feedback type depends largely on the type of task the students are working on. Considering that the sample of participants in this study comprises English teachers in primary education, where emphasis is placed on oral communicative skills, delayed feedback should be somewhat more frequent. Providing immediate feedback in communicative situations whose aim is to develop fluency can lead to weaker performance or slower acquisition of the language. Furthermore, as immediate feedback is more frequent among this sample of participants, we can conclude that teachers tend to use tasks which ask for factual knowledge, or to apply what Jones and William $(2008,6)$ term as initiation-response-feedback (IRF, elaborated by Sinclair and Coulthard 1975), which is characteristic of the early stages of pattern practice where predictable answers are required (e.g., vocabulary sets). However, for the purpose of initiating meaningful communication, such ritualised and rather limiting classroom interactions should be reduced. To address this issue, Harmer $(2015,157)$ suggests gentle correction during oral tasks which imply working on fluency as an intervention that encourages better communication. Awareness of when to provide feedback can be summarised as follows - immediate feedback is useful when referring to factual knowledge (correct/incorrect), while slightly delayed feedback is more appropriate with tasks that ask for thinking and processing. Feedback should not be delayed when it can prompt a student to better achievement. Finally, feedback, as with any other aspect of assessment, must meet the principle of practicality.

\subsection{Feedback Content}

Within this category, the teachers were offered two opposing statements immediately following one another in order to analyse them against each other. The first statement referred to the frequency of providing feedback of a summative character (e.g., good, very good, not correct). According to Wong and Waring (2009), if uttered in a falling intonation such feedback does not invite communication with the teacher, as this intonation indicates an end to any conversation, after which students, in general, will not have the need to say anything. As can be seen in Table 2, $47 \%$ (76) of the teachers said that their feedback is somewhat characterised by such statements, 'very little' was selected by $23 \%(37)$, while around $11 \%$ (18) of the teachers stated that that this is not characteristic of their feedback. However, $18 \%(29)$ of the teachers stated that their feedback is characterised by this to a great extent. 
The next item in the survey referred to the frequency of giving targeted feedback (targeted praise), or according to Scrivener's (2012) term "work-specific praise," which does not end in a falling intonation (e.g., "Great choice of vocabulary in your composition. You only need to check the use of articles with proper nouns."). According to the results (see Table 2), 52.8\% (85) of teachers often use such feedback, indicating what is good or could be improved in the students' work. This is also somewhat characteristic of the feedback given by $41.6 \%$ (67) of participants, with $5 \%$ (8) of the teachers saying that they use this approach very little. To conclude, the teachers' responses show that feedback which is more detailed, and of a formative nature, is more commonly used by our participants.

TABLE 2. Teacher estimates of the frequency of giving summative and formative feedback.

\begin{tabular}{|l|c|c|c|c|}
\hline & \multicolumn{2}{|c|}{ Summative } & \multicolumn{2}{c|}{ Formative } \\
\hline & $\mathbf{f}$ & $\mathbf{\%}$ & $\mathbf{f}$ & $\%$ \\
\hline Not at all & 18 & 11.2 & 1 & 0.6 \\
\hline Very little & 37 & 23 & 8 & 5 \\
\hline Somewhat & 76 & 47.2 & 67 & 41.6 \\
\hline To a great extent & 29 & 18 & 85 & 52.8 \\
\hline No answer & 1 & .6 & & \\
\hline Total & 161 & 100 & 161 & 100 \\
\hline
\end{tabular}

Providing feedback of a formative character requires meticulous work and can initially be rather time-consuming. The teacher must consider the content of the feedback in terms of whether it is productive, clear and useful. The benefit of feedback is in guiding student progress and development, while at the same time improving the teaching process. Instead of feedback such as "well done" or "you can change that," which can be vague for students, more precise feedback such as "try to change the word order in the sentence," "use a synonym," or "check the punctuation," can be more effective, i.e., a combination of the two levels of feedback, FP with regard to the processing of a task, and FR directed at better understanding of a task. Furthermore, effective feedback information can be set in the form of reflection questions for students, such as "Can you use a different word to present your idea more clearly?", "How can you divide this sentence into two or three shorter ones?", "Can you rearrange the paragraphs for better text flow?", or "Can you use adverbs to describe how people worked?" At the same time, asking such questions must be aligned with the level of student ability. Reflection questions imply a degree of student responsibility for their own learning, with the aim of increasing the ownership of learning, responsibility, and motivation.

In defence of summative feedback, it should be noted that summative assessment can be used for a formative purpose. In other words, feedback provided by a test or examination can be formulated in such a way that it can provide guidance for future learning (feeds forward), and consequently future results in learning. Test results can be discussed, and students can use them as a source for determining new learning goals or for planning future learning. To the extent that it is possible, information gathered through assessment of learning should be used by the teacher for formative purposes, and to potentially increase student motivation for learning. It is clear though that feedback from assessment of learning will not be as influential for student learning as feedback based on the two other approaches - assessment as learning and assessment for learning. 
Nevertheless, evidence of student achievement gathered through assessment of learning can also serve as relevant information within the system of ensuring quality education at the level of particular schools, or the entire system of education (Framework for Assessment 2016).

\subsection{Feedback Strategies}

When asked to decide whether they give individual, group feedback or both, the great majority of participants $(81.4 \% ; 131)$ answered that they use both types (Table 3). Almost $15 \%$ (24) of the participants reported that they give only individual feedback, while just $3.7 \%$ (6) stated that they give only group feedback. It can thus be said that the teachers included in the survey seem to balance between giving individual and group feedback, and see the benefits of both types.

TABLE 3. Teacher reports on giving individual and group feedback

\begin{tabular}{|l|c|c|}
\hline & $\mathrm{f}$ & $\%$ \\
\hline Individual feedback & 24 & 14.9 \\
\hline Group / class feedback & 6 & 3.7 \\
\hline Both individual and group feedback & 131 & 81.4 \\
\hline Total & 161 & 100 \\
\hline
\end{tabular}

From a student's point of view, individual feedback is perceived as a message that "the teacher values my learning" (Brookhart 2008). It is also more effective when directed toward specific aspects of student performance or work. Group feedback is efficient when errors can be compiled, as they are common to a certain number of students in a class. However, frequent group feedback is often a strategy that is used when faced with time constraints or having too many students in a class. Although the teachers in our sample use both individual and group feedback, we find it useful to note some issues teachers have with respect to giving adequate individual feedback to their students. Here we provide an excerpt from a teacher's report on this issue:

I feel guilty for not giving much individual feedback to my students. So why can't I? My excuse is that it is extremely time consuming to think of feedback to write at the end of the students' written tasks. I don't want to use just stock phrases, but thinking of different feedback for 30-40 students in 3-5 different courses during one teaching module just feels beyond me. So normally I only resort to it if there is a clear and exceptional case (e.g. somebody has a clearly noticeable problem, or they have improved considerably). I try to alleviate this lack of feedback to some extent by giving oral feedback when handing the written tasks back, though I only have time to do it for some. Students are more or less OK with this (perhaps because they don't know any better!), since they get the grade and can ask if they want more feedback, but it does make me feel inadequate.

(A professor in a centre for foreign languages, from an online E-Teacher Scholarship Program Discussion Board 2011 http://umbc.uoregon.edu/eteacher/)

One possible solution to this problem is giving individual feedback to a number of students relating to one task, followed by a different group and different task, and so on. Between such individual feedback, group feedback can also be given. In this way, the teacher alternates giving informative feedback to a group of students for each task (Pavić 2013). Moreover, a teacher's feedback can have 
more meaning if heard in its entirety, regardless of whether it is directed to an individual or group. In addition to word choice, time, content, and the amount of feedback, there are also strategic guidelines that teachers can follow (ibid.). There are situations when a teacher estimates whether a student is ready to receive feedback and times when the teacher can ask "Would you like to hear my review of your work?" or "Could you use some feedback at this point?"

The following information relates to the amount of feedback, which is also a relevant characteristic. In the literature there is the notion of the "Goldilocks principle," or not too much and not too little, and it is not necessary to comment every error. Table 4 shows the teachers' degree of agreement with the statement It is necessary to comment on all of the student's errors. While the majority $(65.2 \% ; 105)$ do not agree or strongly disagree $(9.3 \% ; 15)$ with the statement, almost $12 \%$ (19) of the teachers agree or strongly agree. A smaller percentage $(13.7 \% ; 22)$ did not express an opinion towards the statement. In examining the participants' answers in this research, we can conclude that the majority adhere to the principle of moderation depending on the task and level of feedback. Still, there is a tendency among teachers, particularly when dealing with written tasks, that they should inform students (highlight or underline) of everything that is not correct in the text, or correct students' oral responses. Error correction is a common concern among teachers. According to Mackey, Park and Tagarelli $(2016,501)$ after decades of research practitioners would agree that correcting all errors is not useful, realistic or possible, but that appropriate corrective feedback is likely to facilitate L2 developmental processes. Learners, it has been established, actually appreciate and welcome corrective feedback, both direct and indirect- however, the type of feedback, and when and how it is given, may determine its usefulness and uptake.

Further research, which would include learners' opinions, could show students' preferences in terms of the amount of error correction in both oral and written tasks and its effects on their learning and motivation. A more detailed study of practices among induction and experienced teachers could also reveal tendencies in providing corrective feedback to students.

TABLE 4. Teachers' estimates of the need to correct all errors. (It is necessary to comment on / correct all of the student's errors).

\begin{tabular}{|l|c|c|}
\hline & $\mathrm{f}$ & $\%$ \\
\hline Strongly disagree & 15 & 9.3 \\
\hline Disagree & 105 & 65.2 \\
\hline Neutral & 22 & 13.7 \\
\hline Agree & 16 & 9.9 \\
\hline Strongly agree & 3 & 1.9 \\
\hline
\end{tabular}

Closely related to error correction are notions of positive and negative feedback. Nordal (2014) established that the terms negative evidence, negative feedback, error correction, and corrective feedback have essentially been used to describe the same phenomena by SLA researchers. In the current research, teachers were asked to give their opinions on the effectiveness of positive and negative feedback. The results show that overall the teachers are not in favour of giving positive feedback. As seen in Table 5, almost half the participants, 49.4\%, do not agree with the statement that only positive feedback is effective. Only $18 \%$ of participants completely agree with the statement, while $30 \%$ could determine whether positive feedback is effective or not. 
Furthermore, more than half the participants (67.7\%) agree with the statement that negative feedback, i.e., information of corrective characteristics, is also effective, and a very small number $(3.1 \%)$ disagree with this notion. Again, as with the previous statement, there are some participants $(26.7 \%)$ who could not express agreement nor disagreement with the statement.

TABLE 5. Teachers' opinions on the effectiveness of positive and negative feedback.

\begin{tabular}{|l|c|c|c|c|c|}
\cline { 2 - 6 } \multicolumn{1}{c|}{} & $\begin{array}{c}\text { Strongly } \\
\text { disagree }\end{array}$ & Disagree & Neutral & Agree & $\begin{array}{c}\text { Strongly } \\
\text { agree }\end{array}$ \\
\hline $\begin{array}{l}\text { Only positive } \\
\text { feedback is effective }\end{array}$ & $3.1 \%$ & $48.4 \%$ & $30.4 \%$ & $17.4 \%$ & $0.6 \%$ \\
\hline $\begin{array}{l}\text { Negative feedback is } \\
\text { also effective }\end{array}$ & & $3.1 \%$ & $26.7 \%$ & $67.7 \%$ & $2.5 \%$ \\
\hline
\end{tabular}

It can be said that in general the participants do not feel that giving only positive feedback is effective. However, there is a significant number of participants $(30.4 \%$ and $26.7 \%)$ who could not express agreement nor disagreement with these statements. We conclude that there is a degree of uncertainty and insecurity related to this issue, and possibly vagueness with regard to what is implied by positive and negative feedback. As such, we offer explanations of negative or corrective feedback and the form that it may take in a classroom (introduced above in About levels, timing and effect of feedback). In writing tasks, explicit feedback can be used in marking errors, which implies that that the students cannot correct themselves. A very common example in teaching English is with collocations or sentence structures. Written corrective feedback is direct when we cross out the error and provide the correction explicitly near or above the error, or when we insert the correct word, morpheme, or phrase (Bitchener and Ferris 2012, 65). Indirect correction is made when the error is only marked (circled or underlined), or the number of errors is recorded in the margin at the end of a given line. Coding can also be considered as indirect correction (Nagode, Pižorn, and Juriševič 2014). Jones and William $(2008,14)$ offer a suggestion that instead of marking every error, the teacher can place a dot in the margin reflecting an error which students then have to identify and correct.

Recently, metalinguistic corrections of students' work have become more common, along with a grammatical rule or example of correct usage and an additional oral explanation (Nagode, Pižorn, and Juriševič 2014). According to Lyster and Ranta (1997, 46-48), the types of corrective feedback in oral tasks can take on the following forms: explicit correction, recasting, clarification requests, metalinguistic feedback, elicitation, repetition, and multiple feedback. In their research, recasting was most widely used in the language classroom. However, although corrective feedback provides negative evidence by signalling that a learner's utterance contained an error, it can also provide positive evidence if the feedback contains the target form (as seen in recasting) (Mackey, Park and Tagarelli 2016, 500).

To differentiate positive feedback from praise, Reigel (2005) offers an expanded definition of oral positive feedback which not only has a metalinguistic component (praise) taking the form of evaluative feedback such as "fine," "good," and "excellent" (Vigil and Oller, 1976), but also a linguistic component (affirmation) and a paralinguistic one (laughter). The latter refers to "Normal conversational responses that one gives in face-to-face situations. Such responses as $u h$ huh or head nodding convey agreement or that the message has been received and is understood 
... can be seen as forms of feedback" (Seliger and Long 1983, 258), while the former include a "personal response" (Imai 1989, 17) - a mechanism of interpersonal communication that includes a speaker and hearer, as manifested by affirmation. Reigel (2005) proposes that teachers issue more affirmation to students, i.e., affirmation of correct utterances.

Regardless of whether feedback is of a positive or negative nature, it should be specific, transparent and effective, meaning it should include instructions as to what to improve and how to do so. Indicating that something is "good" or "bad" without some affirmation and the paralinguistic aspect is neither corrective nor motivational feedback. One can easily imagine a student reflecting on such feedback by asking "What exactly should I do better next time?" Students cannot know what is "good" or "not so good" in their work if this approach is used, and yet according to our research more than $18 \%$ of teachers give such feedback.

The results of our research show that more than half the participants in our sample $(60 \%)$ maintain that students should have opportunities to improve their work after feedback and prior to marking (scoring or grading). Still, there are teachers, although a small percentage $(2 \%)$, who do not agree with this approach and those who have no opinion on it (25\%). According to Black et al. (2004), students react better to assessments if marks are not involved. More precisely, students are prone to ignore comments after being marked. The results of this survey show that teachers are aware of the effect of feedback and are willing to improve their practices, assuming that English language teachers may be inclined to changing their routines and not marking papers immediately but only after giving feedback (oral or written,) which demands further work by the student (and consequently the teacher as well). This is also in agreement with the principles of formative assessment, where, in terms of written work, the exposure of students to the experience of writing is considered a creative process. In that case, we could give feedback which will help students produce a better product - "numerical marks or grades do not inform a student in terms of how to improve their work, and that implies a lost opportunity for progress" (ibid). Students learn while working and after getting feedback. If, on the other hand, the teachers mark work without the students being able make any further corrections, perhaps the teachers can provide the students with the opportunity to do better at another time. This view of assessment is elaborated by Vizek-Vidović et al. $(2003$, 442) in their book Educational Psychology. The authors state that "When it comes to motivation, a good score comes like reinforcement for students. If a student is assigned a bad grade, he/she should be given an opportunity to improve his/her grade. Such an opportunity and feedback on how much they have learned, motivates them to learn more in order to be more successful next time."

This research also uncovered teachers' opinions relating to peer assessment, an essential part of assessment as learning, i.e., the formative approach to assessment. According to MacDonald et al. $(2015,42)$, formative feedback can come from many sources, the most common being teachers, peers and students themselves through self-reflection and self-assessment. The results of the current study's survey show that $68.3 \%$ of the teachers agree and $13.66 \%$ strongly agree that if given guidance then students could give effective feedback to peers. A smaller percentage of teachers remained neutral on this issue (15.53\%), while only $2.48 \%$ disagreed with the statement that peer feedback is useful for student learning. It is thus evident that teachers realize the potential of involving students in giving feedback, i.e., peer assessment prior to giving a summative evaluation. The more experience students have in assessing their own or peers' learning and achievement, the more they will be able to regulate their own learning based on 
the information they have generated in the self-assessment process. Initially, the teacher models feedback offering support for independent learning and understanding and in applying strategies that will promote progress in learning. Later, students gradually create their own feedback according to the teacher's guidelines.

\subsection{How Does Feedback Affect My Students?}

If given in a way that students recognize as effective in terms of invoking change and progress, feedback is effective and motivating. According to the results of this research, more than half of the participants $53.4 \%$ (86) find that students sometimes experience anxiety when receiving feedback, while $31.1 \%$ (50) consider this to be a frequent occurrence. However, for $15.5 \%$ (25) of the participants this is never the case. Around a quarter of the participants $(26.7 \%$; 43$)$ find that feedback always has a motivational influence on students, with most of the respondents $(71.4 \%, 115)$ claiming this is frequently the case. A small number of the participants said that feedback has no motivational influence on their students. Furthermore, most of the participants feel that feedback does not encourage peer competition, but often encourages students to improve themselves. According to the results, the English language teachers surveyed in this work agree that feedback improves learning. That is in agreement with research (Gass and Selinker 2001) which says that motivation, as a social psychological factor, is a predictor of success in foreign language learning. Furthermore, according to Čačinovič Vogrinčič (2008, as cited in Nagode, Pižorn, and Juriševič 2014), the rules of supportive and positive communication can and should be generally applied when working with people, and hence also in the teacher-student relationship. It is only communication of this kind that leads to a supportive, cooperative, equal, and at the same time very active student/teacher relationship. The teacher's positive approach is also most important in the case of giving (written) corrective feedback, regardless of the approach applied. We can perhaps ascribe rather the frequent presence of anxiety in receiving feedback to teacher-student communication that lacks some of the characteristics of supportive positive communication. Or perhaps we can take this a step further. If feedback is frequently of a corrective and summative nature, and students do not have the opportunity to improve their performance after receiving it (the results show that $25 \%$ of the teachers are not sure whether or not such opportunities should be given), then it is not surprising that students experience anxiety when receiving feedback. However, here we must take into consideration that the teachers' answers to this set of questions express their opinions, implying that further research should include also student's responses, as this would provide a more objective view of the effects of feedback in a language classroom.

TABLE 6. Teacher opinions on how feedback affects their students

\begin{tabular}{|l|c|c|c|c|c|}
\hline & $\begin{array}{c}\text { Anxiety } \\
\%(f)\end{array}$ & $\begin{array}{c}\text { Motivation } \\
\%(f)\end{array}$ & $\begin{array}{c}\text { Encourages peer } \\
\text { competition } \\
\%(f)\end{array}$ & $\begin{array}{c}\text { Encourages } \\
\text { personal } \\
\text { improvement } \\
\%(f)\end{array}$ & $\begin{array}{c}\text { Improves } \\
\text { learning } \\
\%(f)\end{array}$ \\
\hline Never & $15.5 \%(25)$ & $6 \%(1)$ & $59.01 \%(95)$ & $1.86 \%(3)$ & $.62 \%(1)$ \\
\hline Sometimes & $53.4 \%(86)$ & $1.2 \%(2)$ & $31.68 \%(51)$ & $10.56 \%(17)$ & $1.86 \%(3)$ \\
\hline Frequently & $31.1 \%(50)$ & $71.4 \%(115)$ & $4.35 \%(7)$ & $70.81 \%(114)$ & $72.05 \%(116)$ \\
\hline Always & & $26.7 \%(43)$ & $4.79 \%(8)$ & $13.15 \%(26)$ & $25.47 \%(41)$ \\
\hline
\end{tabular}




\subsection{Assessment of Teacher Competence and Need for Improvement}

The results in Table 7 show that $90.7 \%$ of the participants expressed concern regarding their competence in giving feedback to students. Only $10 \%$ of the teachers assessed themselves as relatively competent in providing effective and useful feedback, and more than half (67.1\%) reported that this is an area in which they could use more training and professional development.

TABLE 7. Teachers' estimates on their competence in providing feedback and need for further professional development.

\begin{tabular}{|l|c|c|}
\hline & YES & NO \\
\hline Competence in giving feedback to students & $9.3 \%$ & $90.7 \%$ \\
\hline Need for professional development & $67.1 \%$ & $32.3 \%$ \\
\hline
\end{tabular}

The participants' responses show that English language teachers are open and willing to improve their effectiveness in providing feedback. What is more, they also express a need for further learning and training in the area of assessment. This finding is consistent with the results of a previously conducted research in Croatia in 2010 (Cindrić) where 74 primary school English language teachers reported having received no or limited formal education in the area of assessment or self-assessment during their pre-service teacher training. What is more, the participants, regardless of work experience, also reported having had few opportunities for inservice training and professional development in this area (ibid). The need for improvement in assessment practices and feedback resurfaces in the present study, urging for measures to be taken. Since 2005, the Faculty of Teacher Education, University of Zagreb has been offering a course English Language Teaching Methodology: Assessment within the Programme for the Undergraduate and Graduate Study of Primary Teaching and the English Language (2005), introducing topics of assessment to pre-service teachers. In-service training offered by the teacher training agency occasionally focuses on assessment issues; however, these attempts only partially remedy concerns teachers have relating to assessment. What is lacking is a comprehensive assessment system and a developed assessment policy for primary schools aligned with the curriculum at the state level. Once the curriculum and complementary assessment framework are in place, coordination with pre-service teacher training institutions and the teacher-training agency can be established in order to offer more structured, applicable, and progressively more challenging continuing professional development. That would be a start for effectively meeting foreign language teachers' recurring needs in the area of assessment and feedback.

\section{Conclusion}

The research conducted on a sample of 161 primary school English language teachers revealed general information on the feedback used in foreign language teaching, and more specifically on the related tendencies, characteristics and needs. Based on the participants' responses to the survey, we were able to answer the first research question, and thus established that the English language teachers in this sample frequently give feedback to their students. Moreover, they generally describe their feedback as immediate. This indicates that feedback is given for examining or checking at the level of remembering, or if referring to level of feedback - at the task level (FT). Although initial foreign language teaching relies on students' ability to recognize, show, identify, name, list, and so on, it is also necessary to gradually include communicative 
language tasks that ask for understanding, comprehension, analysis, and application, since communicative competence is emphasised in language teaching. Such tasks do not necessarily demand immediate feedback, but delayed feedback or intervention from the teacher. In the research conducted in this study, only half of participants give delayed feedback regularly, while others give it occasionally or never. Here we point to research by Yoshida (2010), which shows that learners tend to prefer receiving feedback such as clarifications or elicitations in order to work out the correct answers themselves, rather than receiving the correct forms immediately after their erroneous utterances. Therefore, with respect to this research, we can say that the results do not necessarily speak about whether teachers give appropriate feedback, but instead indicate that the tasks that encourage thinking and processing are somewhat less represented in their teaching than tasks at the level of remembering. The results indicate that more training should be given to teachers at both pre-service and in-service levels with respect to aligning task and assessment, i.e., feedback in foreign language teaching.

Feedback in the form of a short answer ("good," "bad," "very good") uttered in a falling intonation is used by the participants sometimes or rarely, indicating that teachers are aware of the rather negative and vague effects of such feedback. The answer to the second research question indicated that targeted feedback of a formative character is much more frequent in the sample. However, the research revealed an area where teachers expressed insecurity, i.e., they could not provide an answer as to whether positive and negative feedback is useful for students. In that respect, it is necessary to clarify what the two notions imply, and when and how they can be implemented in order to be most effective. Almost all the participants offer both group and individual feedback. They also estimated that feedback mostly has a motivational effect on their students. However, what is of concern and must be addressed is that the teachers observe anxiety among students when they receive feedback, and not only occasionally, but frequently. This can perhaps be linked with the answer to the second research question, which showed that students receive mostly corrective, immediate feedback, or that they do not have time to follow up on the feedback. Another aspect which should be looked at in more detail is teacher-student rapport when feedback is given and received, which if not positively uttered can cause anxiety for students. The English language teachers in this sample seem to be aware of the usefulness of feedback, and show an awareness of the need to include peer feedback into the assessment process, but are also cautious about this issue, as seen in those participants who did not have a clear opinion, indicating insecurity or perhaps lack of experience in carrying out peer assessment.

Lastly, almost all of participants expressed the need to improve their competence in giving feedback. We conclude that more training, information, and opportunities for applying formative assessment in classroom practices are necessary. That implies introducing and practicing the principle of formative assessment in pre-service teacher education and targeted professional development that closely follows changes in the curriculum.

This research showed that English language teachers have recognised the responsibility they have in carrying out effective assessment, including feedback not only in the assessment of learning approach, as is often the case, but in the other two approaches as well. It also revealed areas where teachers are lacking in confidence or otherwise insecure (corrective feedback, peer feedback, and communicating feedback to students). Properly addressing these needs, and doing more detailed research into the issues raised here, would perhaps enable teachers to carry out more valid and appropriate assessments of student abilities and achievements, in ways that are aligned with the assessment for learning approach advocated in the educational strategy. 


\section{References}

Bennett, Randy Elliot. 2011. "Formative Assessment: A Critical Review." Assessment in Education: Principles, Policy \& Practice 18 (1): 5-25. http://dx.doi.org/10.1080/0969594X.2010.513678.

Bitchener, John, and Dana R. Ferris. 2012. Written Corrective Feedback in Second Language Acquisition and Writing. New York: Routledge.

Bitchener, John, Stuart Young, and Denise Cameron. 2005. "The Effects of Different Types of Corrective Feedback on ESL Student Writing." Journal of Second Language Writing 14 (3): 191-205. http://dx.doi. org/10.1016/j.jslw.2005.08.001.

Black, Paul, and Dylan William. 1998. Inside the Black Box. London: Kind's College.

Black, Paul, Christine Harrison, Clare Lee, Bethan Marshall, and Dylan William. 2004. "Working Inside the Black Box: Assessment for Learning in the Classroom.” Phi Delta Kappan 86 (1): 8-21. http://dx.doi. org/10.1177/003172170408600105.

Brookhart, Susan M. 2008. How to Give Effective Feedback to Your Students. Alexandria: Association for Supervision and Curriculum Development. http://perino.pbworks.com/f/Effective+Feedback.pdf.

Burnett, Paul C. 2001. "Elementary Students' Preferences for Teacher Praise." Journal of Classroom Interaction 36 (1): 16-23. http://www.jstor.org/stable/23870540.

Clariana, Roy B., Daren Wagner, and Lucia C. Roher Murphy. 2000. "Applying a Connectionist Description of Feedback Timing." Educational Technology Research and Development 4/8 (3): 5-22. http://dx.doi. org/10.1007/BF02319855.

Chomsky, Noam. 1975. Reflections on Language. New York: Pantheon.

Cindrić, Ivana. 2010. "Teacher Assessment Competences in Primary Education English Foreign Language Learning.” PhD diss., Faculty of Arts, University of Ljubljana.

Čačinovič Vogrinčič, Gabi. 2008. Soustvarjanje v šoli: učenje kot pogovor [Cooperation in School: Teaching as Conversation]. Ljubljana: Zavod RS za šolstvo.

Doughty, Catherine, and Elizabeth Varela. 1998. “Communicative Focus on Form.” In Focus on Form in Classroom Second Language Acquisition, edited by Catherine Doughty and Jessica Williams, 114-38. New York: Cambridge University Press.

Doughty, Catherine, and Jessica Williams. 1998. "Pedagogical Choices in Focus on Form." In Focus on Form in Classroom Second Language Acquisition, edited by Catherine Doughty and Jessica Williams, 197-261. New York: Cambridge University Press.

Dunn, Karee E., and Sean W. Mulvenon. 2009. "A Critical Review of Research on Formative Assessment: The Limited Scientific Evidence of the Impact of Formative Assessment in Education.” Practical Assessment, Research and Evaluation 14 (7): 1-11.

El Tatawy, Mounira. 2002. "Corrective Feedback in Second Language Acquisition." Working Papers in Applied Linguistics and TESOL 2 (2): 1-19. http://dx.doi.org/10.7916/D8HM5N0N.

E-Teacher Scholarship Program. 2011. http://umbc.uoregon.edu/eteacher/.

Faculty of Teacher Education. 2005. "Programme of the Undergraduate and Graduate Study of Primary Education (A Major) in Combination with the Study of the English Language (B Major)." Zagreb: Faculty of Teacher Education, University of Zagreb.

Fluckiger, Jarene, Yvonne Tixier y Vigil, Rebecca Pasco, and Kathy Danielson. 2010. "Formative Feedback: Involving Students as Partners in Assessment to Enhance Learning.” College Teaching 58 (4): 136-40. http://dx.doi.org/10.1080/87567555.2010.484031. 
Gass, Susan, M. 1988. “Second Language Vocabulary Acquisition.” Annual Review of Applied Linguistics 9: 92-106.

—. 1990. "Second and Foreign Language Learning: Same, Different or None of the Above?" In Second Language Acquisition, edited by Bill Van Patten and James F. Lee, 34-44. Clevedon, UK: Multilingual Matters.

Gass, Susan M., and Larry Selinker. 2001. Second Language Acquisition - An Introductory Course. London: Lawrence Earlbaum. http://blogs.umass.edu/moiry/files/2015/08/Gass.Second-Language-Acquisition.pdf.

Harmer, Jeremy. 2015. The Practice of English Language Teaching. Essex: Pearson Education Ltd.

Hattie, John, and Helen Timperley. 2007. "The Power of Feedback.” Review of Educational Research 77 (1): 81-112. https://doi.org/10.3102/003465430298487.

Imai, Junko. 1989. "Comparative study on effectiveness of corrective/noncorrective techniques in EFL classes at college level in Japan.” MA TESOL thesis, Portland State University, Portland.

Jones, Jane, and Dylan William. 2008. "Modern Foreign Languages inside the Black Box." In Assessment for Learning in the Modern Languages Classroom, edited by P. Black, C. Harrison, M. Bethan, and D. William. London: GL Assessment.

Krashen, Stephen D. 1982. Principles and Practice in Second Language Acquisition. http://www.sdkrashen.com/ content/books/principles_and_practice.pdf.

Kuo, Huang Ru. 2003. "The Nature and Causes of Interlanguage Fossilization.” The Source Online Journal of Education. University of Southern California, USC Rossier School of Education.

Lightbown, Patsy M., and Nina Spada. 1990. "Focus-on-form and Corrective Feedback in Communicative Language Teaching: Effects on Second Language Acquisition." Studies in Second Language Acquisition 12 (4): 429-48. http://dx.doi.org/10.1017/S0272263100009517.

Long, Michael H. 1983. "Native Speaker/Non-Native Speaker Conversation and the Negotiation of Comprehensible Input." Applied Linguistics 4 (2), 126-41. http://doi.org/10.1093/applin/4.2.126.

Lyster, Roy, and Leila Ranta. 1997. "Corrective Feedback and Learner Uptake: Negotiation of Form in Communicative Classrooms." Studies in Second Language Acquisition 19 (1): 37-66. https://www. cambridge.org/core/journals/studies-in-second-language-acquisition/article/corrective-feedback-andlearner-uptake/59229F0CA2F085F5F5016FB4674877BF.

MacDonald, Rita, Timothy Boals, Mariana Castro, Gary H. Cook, Todd Lundberg, and Paula A. White. 2015. Formative Language Assessment for English Learners. Portsmouth: Heinemann.

Mackey, Alison, Hae In Park, and Kaitlyn M. Tagarelli. 2016. “Errors, Corrective Feedback and Repair.” In The Routledge Handbook of English Language Teaching, edited by Graham Hall, 499-513. London, New York: Routledge Handbooks.

Ministry of Science, Education and Sports. 2006. Curriculum for Primary School [Nastavni plan i program za osnovne škole]. Zagreb.

- 2010. Croatian National Educational Standard [Hrvatski nacionalni obrazovni Standard]. Zagreb. https:// mzo.hr/en/rubrike/croatian-national-educational-standard-cnes.

—. 2016. Framework for the Assessment of Learning Processes and Outcomes (Draft) [Prijedlog Okvira za vrednovanje procesa i ishoda učenja]. Zagreb. https://mzo.hr/sites/default/files/migrated/prijedlog_ okvira_za-vrednovanje_os_ss_nakon_strucne_rasprave.pdf.

Mueller, Claudia, and Carol S. Dweck. 1998. "Intelligence praise can undermine motivation and performance." Journal of Personality and Social Psychology 75 1: 33-52. http://www.itari.in/categories/ ability_to_learn/praise_for_intelligence_can_undermine_childrens.pdf. 
Nagode, Gabrijela Petra, Karmen Pižorn, and Mojca Juriševič. 2014. “The Role of Written Corrective Feedback in Developing Writing in L2.” ELOPE 11 (2): 89-98. http://dx.doi.org/10.4312/ elope.11.2.89-98.

Nordal, Erdal. 2014. "Negative Feedback Perceptions and Practices regarding the Correction of Oral English Errors in Norwegian Upper Secondary Schools." MA Thesis, Faculty of Humanities, University of Oslo.

Pavić, Snježana. 2013. Assessment: Embracing New Challenges. Aberdeen: Inspired by Learning.

Petchprasert, Anongnad. 2012. "Feedback in Second Language Teaching and Learning." US-China Foreign Language 10 (4): 1112-20. http://www.libarts.up.ac.th/data/psn_research/1364788849.pdf.

Ramaprasad, Arkalgud. 1983. "On the Definition of Feedback.” Behavioral Science 28: 4-13. http://dx.doi. org/10.1002/bs.3830280103.

Reigel, David. 2005. "Positive Feedback Loops in Second Language Learning." MA - TESOL thesis, Portland State University.

Sadler, Royce. 1989. "Formative Assessment and the Design of Instructional Systems." Instructional Science 18 (2): 119-44. http://dx.doi.org/10.1007/BF00117714.

Schmidt, Richard. 1990. "The Role of Consciousness in Second Language Learning." Applied Linguistics 11 (2): 129-158. http://dx.doi.org/10.1093/applin/11.2.129.

-. 1995. "Consciousness and Foreign Language Learning: A Tutorial on the Role of Attention and Awareness in Learning." In Attention and Awareness in Foreign Language Learning, edited by Richard Schmidt, 1-63. Honolulu. University of Hawaii Press.

Schmidt, Richard, and Sylvia Frota. 1986. "Developing basic conversational ability in a second language: A case study of an adult learner of Portuguese." In Talking to Learn: Conversation in Second Language Acquisition. Edited by Richard Day. 237- 326. Rowley, MA: Newbury House. http://nflrc.hawaii.edu/ PDFs/SCHMIDT\%20Developing\%20basic\%20conversational\%20ability\%20in\%20a\%20second\%20 language.pdf

Scrivener, Jim. 2012. Classroom Management Techniques. Cambridge: Cambridge University Press.

Seliger, Herbert W., and Michael M. Long. 1983. Classroom Oriented Research in Second Language Acquisition. Rowley, MA: Newbury House Publishers, Inc.

Sinclair, John McHardy, and Malcolm Coulthard. 1975. Towards an Analysis of Discourse. Oxford: Oxford University Press.

U.S. Department of Education. 2001. “The Elementary and Secondary Education Act.” http://www2.ed.gov/ policy/elsec/leg/esea02/index.html.

—. 2015. "Every Student Succeeds Act."

Varnosfadrani, Azizollah D., and Helen Basturkmen. 2009. “The Effectiveness of Implicit and Explicit Error Correction on Learners 'Performance.” System 37 (1): 82-98. http://dx.doi.org/10.1016/j. system.2008.04.004.

Vigil, Neddy A., and John Oller. 1976. "Rule Fossilization: A Tentative Model." Language Learning 26: 14862. http://dx.doi.org/10.1111/j.1467-1770.1976.tb00278.x.

Vizek-Vidović, Vlasta, Dubravka Miljković, Majda Rijavec, and Vesna Vlahović-Štetić. 2014. Psihologija obrazovanja. Zagreb: IEP d.o.o. - VERN Zagreb.

Wong, Jean, and Hansun Zhang Waring. 2009. "Very good" as a Teacher Response. ELT Journal 63 (3): 195203. http://dx.doi.org/10.1093/elt/ccn042.

Yoshida, Reiko. 2010. “Teachers' Choice and Learners' Preference of Corrective Feedback Types.” Language Awareness 17 (1): 78-93. http://dx.doi.org/10.2167/la429.0. 